\title{
ANALISA NARASI TENTANG RELASI DAUD DENGAN ABSALOM DALAM 2 SAMUEL 13-19
}

\author{
Gumulya Djuharto
}

\section{ABSTRAKSI}

Penelitian terhadap relasi Daud dengan Absalom menjadi pelajaran berharga terkait relasi orang tua dengan anak, khususnya relasi seorang ayah dengan anak laki-lakinya. Setelah membaca teks seputar Daud dan Absalom, penulis diyakinkan bahwa masalah relasi yang tidak terjalin konstruktif di antara keduanya diakibatkan oleh hilangnya komunikasi langsung dua arah di antara mereka berdua. Hilangnya jenis komunikasi seperti itu coba dilengkapi oleh narator melalui berbagai cara. Pertama, menampilkan peran Absalom terhadap Tamar pasca pemerkosaan yang dilakukan Amnon, yang sebenarnya lebih tepat bila peran tersebut dilakukan oleh Daud sebagai ayah kandung Tamar: memahami permasalahan yang terjadi dan perasaan Tamar; menolong Tamar melewati masa sulit dan membelanya; memberikan ketenangan emosional kepada Tamar. Kedua, menampilkan ketidakpekaan Daud terhadap permintaanpermintaan Absalom yang berujung pada pembunuhan terhadap Amnon. Penulis melihat jika Daud memenuhi permintaan untuk hadir dalam acara pengguntingan bulu domba, pertumpahan darah tidak akan terjadi. Ketiga, melalui nasihat tidak langsung dari perempuan Tekoa melalui rekayasa kasus yang sebenarnya mengandung tindakan-tindakan penting yang seharusnya dilakukan Daud, antara lain: menjadi penengah di tengah konflik yang terjadi; mencegah agar konflik tidak makin meluas; menyelesaikan masalah dengan bijak; menyampaikan kata-kata yang menenangkan hati; dan memberikan teladan hidup. Penulis melihat semuanya ini adalah pemaparan tentang sisi melankolis Daud yang justru melemahkan kepemimpinan Daud, khususnya kepemimpinan dalam keluarga. Ironisnya, melalui pemaparan relasi dengan anak buah dan rekan-rekannya, Daud justru menampilkan sisi melankolis, yang bukan melemahkan, melainkan justru memperkuat sisi kolerik kepemimpinan Daud. Akhirnya, penulis melihat bahwa semua tragedi di tengah keluarga Daud 
seharusnya dapat diselesaikan dan tidak makin melebar apabila Daud meneladani mentalitas Ahimaas yang bertindak bukan untuk memuaskan pribadi tertentu, atau bukan untuk mendapatkan keuntungan, atau bahkan bukan untuk mendapatkan posisi penting atau penghargaan orang lain melainkan kerinduan yang besar untuk menyatakan kebenaran yang bila semuanya ini dilakukan dengan bijaksana, dia akan menjadi pemimpin yang tidak pernah menggadaikan kebenaran yang diyakininya. Bahkan, dia berpotensi menjadi pemimpin yang menjadi agen perubahan bagi orang-orang dan lingkungan sekitarnya.

Kata kunci : Relasi orang tua dengan anak, Sisi melankolis dan kolerik Daud, Kepemimpinan Daud, Kebijaksanaan

\section{PENDAHULUAN}

Sekilas terlihat bahwa narasi dalam 2 Samuel 13-19 ${ }^{1}$ tentang relasi Daud dengan Absalom tercatat cukup panjang. Namun sesungguhnya, narasi tentang relasi keduanya lebih terlihat seperti serpihan-serpihan kecil dalam keseluruhan narasi yang cukup panjang. Tidak tercatat komunikasi berupa kutipan langsung (atau tidak langsung) dalam bentuk percakapan di antara keduanya. Yang ada adalah komentar satu pihak (entah Daud atau Absalom) terhadap pihak lainnya (entah Absalom atau Daud). Bahkan penulis melihat begitu banyak tindakan reflektif yang dilakukan pihak lain, misalnya Absalom, yang seharusnya dilakukan oleh Daud, demikian juga sebaliknya. Bahkan juga tindakan reflektif yang dilakukan pribadi lain di luar Daud atau Absalom, yang

\footnotetext{
${ }^{1}$ Saya mengikuti Conroy, yang dikutip oleh P. Kyle McCarter, Jr., "Plots, True or False" dalam Interpretation 35/4 (Oktober 1981) 363, yang mengatakan bahwa 2 Samuel 13-20 adalah unit literatur tersendiri yang berawal dan berakhir pada relasi Daud dan Absalom yang bertujuan memberitahukan kepada publik tentang peristiwa yang bersifat pribadi di kalangan kerajaan dan apa tindakan Daud sebagai raja. Tetapi penulis tidak setuju bahwa ini pasti bertujuan membela Daud. Bahkan penulis meyakini bahwa meskipun unit ini adalah bagian dari unit yang lebih besar, yang dikenal sebagai Succession Narrative (yaitu narasi yang menunjukkan kelanjutan suksesi dari Daud kepada Salomo), tidak serta merta diartikan bahwa itu selalu propaganda mendukung kebijakan pihak kerajaan. Dalam providensia Allah, saya yakin penulis mencatat semuanya itu juga sebagai peringatan tentang efek berantai dosa yang tidak diselesaikan dengan cara yang baik, meskipun suksesi kepemimpinan dari Daud ke Salomo tetap dapat terjadi, khususnya karena janji tak bersyarat Tuhan dalam Perjanjian Tuhan dan Daud dalam 2 Samuel 7. Tetapi mengingat pasal 20 tidak menceritakan kisah Daud dan Absalom, penulis tidak membahasnya dalam tulisan ini.
} 
seharusnya dilakukan oleh Daud atau Absalom. Dengan kata lain, penulis melihat dan mengajukan presuposisi bahwa dalam narasi 2 Samuel 13-19 tidak terdapat relasi konstruktif di antara Daud dan Absalom. Dan analisa terhadap teks-teks dalam 2 Samuel 1319 berusaha membuktikan presuposisi di atas.

\section{ANALISA NARASI 2 SAMUEL 13-20}

\section{ANALISA 2 SAMUEL 13:20-22}

2 Samuel 13:20-22 merupakan reaksi tentang akhir tragis sebuah kisah percintaan satu pihak dan terlarang. Penulis melihat reaksi-reaksi itu disusun dalam bentuk kiasmus sebagai berikut:

A. Reaksi Absalom terhadap Tamar (ay. 20)

B. Reaksi Daud terhadap Amnon (ay. 21)

\section{A'. Reaksi Absalom terhadap Amnon (ay. 22)}

Berdasarkan bentuk kiasmus di atas, terlihat bahwa reaksi Daud seharusnya menjadi pusat perhatian pembaca. Namun setelah membaca teks ini (ay. 20-22), pembaca patut kecewa karena reaksi Daud terlalu minim; jauh tertinggal dengan reaksi Absalom yang ditampilkan dalam teks dalam struktur yang mengapit reaksi Daud. Menilik penyebutan "Absalom bin Daud" dan "Amnon bin Daud" dalam 13:1, patut diduga bahwa narator ingin menggiring pembaca kepada peran dan kepemimpinan Daud sebagai ayah dari Absalom dan Amnon. Sayangnya selain kemarahan $^{2}$, peran dan kepemimpinan Daud sebagai seorang

2 Rata-rata catatan kemarahan yang dicatat dalam Alkitab segera disertai tindakan tertentu (lihat Kej. 4:5; 30:2; 31:35; Kel. 4:14; Ayub 19:11; Mzm. 37:1; Ams. 24:19; Yes. 41:11; 45:24). Kemarahan (atau penyesalan, yaitu kemarahan di dalam hati) tanpa tindakan nyata tercatat dalam Kej. 45:5 tentang komentar positif Yusuf bahwa mungkin saja di antara saudara-saudaranya ada yang menyesali tindakan mereka membuang Yusuf setelah peristiwa itu terjadi, tetapi tidak dapat berbuat apa-apa. Kondisi seperti inilah yang mungkin terjadi pada Daud: ia marah terhadap apa yang terjadi, tetapi ia tidak mampu berbuat apaapa. Danna Nolan Fewell dan David M. Gunn, Gender, Power and Promise (Nashville, TN: Abingdon, 1993) 145, menyebutkan bahwa ketidakhadiran nyanyian keluhan Daud seperti waktu Absalom terbunuh, misalnya: "Oh anak perempuanku, Tamar, anak perempuanku, anak perempuanku Tamar! Oh seandainya aku tidak mengirimkan engkau ke rumah anak lelakiku, Oh Tamar, 
ayah sama sekali tidak tampak sehingga narator mengakhiri narasi tentang relasi Amnon dan Tamar dengan nada negatif, dengan tidak disebutkannya peran Daud sebagai seorang ayah yang mengayomi anak-anaknya. Diane Jacobson menyebut "David ... is most present through his absence." Artinya, kehadiran Daud dalam teks ditunjukkan melalui ketidakhadirannya sebagai ayah yang melindungi anak-anaknya. Sekali lagi teks 2 Samuel 13 menyiratkan hal ini. Sementara Absalom dan Amnon disebutkan sebagai anak Daud, tidak satu kalipun penyebutan Tamar disertai dengan ungkapan "Tamar, anak Daud" melainkan "Absalom bin Daud mempunyai seorang adik perempuan yang cantik, namanya Tamar" (ayat 1). Ini menyiratkan bahwa Absalomlah yang menjadi seperti ayah bagi adiknya, Tamar, dan bukan Daud. Jacobson menyimpulkan bahwa "David, who has eyes for so many other women, has no eyes at all for his own daughter."

Meneliti lebih jauh bentuk kiasmus di atas, penulis meyakini bahwa narator sedang membuat refleksi tentang "ketidakhadiran Daud" melalui kehadiran tokoh lainnya, dalam hal ini Absalom. Bila motif balas dendam Absalom terkait Tamar digantikan dengan motif yang benar, ada beberapa cara Absalom menangani kasus Tamar, yang ternyata tidak dilakukan Daud:

1. Memahami permasalahan yang terjadi dan perasaan yang dialami Tamar. Pertanyaan Absalom dalam bahasa Indonesia terlihat sedikit lebih vulgar ("Apakah Amnon, kakakmu itu, bersetubuh dengan engkau?") dibandingkan dengan terjemahan dari bahasa Ibrani ("Apakah Amnon kakakmu telah bersama-sama dengan engkau?") yang menurut Alter adalah penggunaan gaya bahasa eufemisme (dengan penggunaan

anak perempuanku, anak perempuanku," menunjukkan bahwa kemarahan Daud hanyalah ungkapan frustrasi terhadap tingkah laku Amnon. Baruch Halpern, David's Secret Demons (Grand Rapids, MI: Eerdmans, 2001) menambahkan bahwa ketidakmampuan Daud bertindak karena dia sendiri telah melakukan dosa yang mirip dengan Amnon yaitu berzinah dengan Batsyeba.

3 Diane Jacobson, "Remembering Tamar," dalam Word \& World 24/4 (Fall 2004) 355.

4 Jacobson, 355.

5 Teks menyajikan penghilangan (omission) yang biasa dikenal dengan teknik " gapping " untuk menunjukkan ketidakhadiran peran Daud dalam situasi yang krusial ini. Tentang penghilangan dan " gapping," lihat Tremper Longman III, "Literary Approaches to Biblical Interpretation," in Foundations of Contemporary Interpretation (ed. Moises Silva; Grand Rapids, MI: Zondervan, 1996), 154. 
kata-kata yang lebih halus dan tidak langsung) menggantikan kata " memperkosa ", yang dipahami sebagai usaha hati-hati Absalom dalam memperlakukan adik perempuannya yang hancur hatinya dengan lembut agar tidak bertambah sakit hatinya. ${ }^{6}$ Peran ini seharusnya juga dilakukan oleh Daud tetapi sayangnya itu tidak pernah terjadi. Anne Apple menyebutkan 3 buah pengandaian dalam kasus Amnon dan Tamar, dan salah satunya terkait dengan peran lingkungan sekitar yang tidak permisif terhadap tindakan kekerasan seksual seperti yang dialami oleh Tamar. ${ }^{7}$ Faktanya, tidak ada catatan tentang Daud yang mendatangi dan mencoba menghibur Tamar seperti yang dilakukan oleh Absalom. Ini menunjukkan tindakan permisif Daud terhadap apa yang dilakukan oleh Amnon, yang menghasilkan " bola liar " yang akhirnya ditangkap oleh Absalom. Sayangnya, Absalom menenangkan Tamar bukan untuk meredakan masalah, tetapi meredakan situasi untuk sementara waktu, dan menunggu momen yang tepat untuk membalaskan sakit hati adiknya kepada Amnon.

2. Menolong Tamar melewati masa sulit dan membela Tamar. Frase "dan sekarang, adik perempuanku, buatlah (dirimu) diam (karena) itu adalah kakakmu" bersama-sama dengan frase "jangan terlalu memikirkan perkara itu" yang secara literal berarti "jangan menaruh/menetapkan (hal itu) di hatimu" merupakan nasihat agar Tamar tidak membiarkan perkara itu terus menetap di dalam hatinya. Dengan kata lain, jangan membiarkan rasa sakit di hati terus menyakiti hidupnya secara keseluruhan. Kalau dilihat secara seksama, khususnya dalam ungkapan "itu adalah kakakmu", ini seharusnya lebih tepat diucapkan oleh Daud karena statusnya sebagai ayah bagi Tamar, Amnon, dan bahkan Absalom. Namun sekali lagi

${ }^{6}$ Robert Alter, The David Story: A Translation with Commentary of 1 and 2 Samuel (New York, NY: W. W. Norton, 1999), 270, memakai kata "tear-stained, disheveled sister" (adik perempuan yang rambutnya berantakan [karena] tangisan yang susah sekali untuk dihilangkan/dihentikan) untuk kondisi Tamar, sedangkan perlakuan Absalom digambarkan dengan "delicacy of feeling" (perasaan yang sangat lembut atau nyaman).

7 Anne Apple, "The Rape of Tamar," dalam Journal for Preachers 36/2 (Lent 2013) 38. Dua pengandaian lainnya adalah " seandainya Yonadab memberikan nasehat yang baik" dan "seandainya Amnon tidak pura-pura sakit".

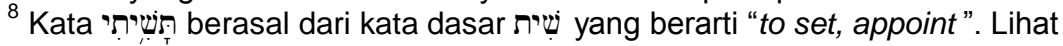
Francis Brown, S. R. Driver, and Charles A. Briggs, Hebrew and English Lexicon of the Old Testament (Peabody, MA: Hendrickson, 1996), 1011. 
terbukti bahwa Daud tidak hadir dalam situasi emosional yang kritis, yang dialami oleh Tamar, anak perempuannya. Dengan mengamati lebih dalam kata "diam" yang juga bisa berarti "keep still, be silent, keep inactive, let someone do something without objection" (tetap diam, menjadi tidak bersuara, tetap tidak aktif, membiarkan seseorang melakukan sesuatu tanpa penolakan), ${ }^{9}$ dapat dipahami bahwa Absalom sedang menasihati Tamar untuk tidak melakukan sesuatu yang merusak atau destruktif, baik terhadap dirinya sendiri maupun terhadap Amnon. Tetapi kalau menilik komentar di ayat 22 tentang sikap diam Absalom tetapi disertai kebencian terhadap Amnon, dapat disimpulkan bahwa Absalom mencegah Tamar melakukan sesuatu yang destruktif karena Absalomlah yang akan mengambil alih tindakan yang diperlukan untuk meredakan atau menghilangkan rasa sakit di hati Tamar. Dan di dalam narasi selanjutnya jelas terlihat: bahkan setelah 2 tahun, kebencian dan dendam di hati Absalom tidak pernah pudar. Jadi, tindakan diam Absalom hanyalah cara untuk menunggu waktu dan saat yang tepat untuk melakukan balas dendam. ${ }^{10}$ Seharusnya, bila kepemimpinan Daud eksis di tengah keluarganya, pasti ada catatan tentang teguran atau hukuman tertentu terhadap Amnon dan bukannya pembunuhan seperti yang dilakukan Absalom. Jelas terlihat di sini bahwa ketidakhadiran seorang pemimpin terkait dengan tanggung jawab kepemimpinannya, dalam konteks ini adalah kepemimpinan di dalam keluarga, harus dibayar dengan sangat mahal. Ketidakhadiran seorang pemimpin pasti akan digantikan oleh orang lain. ${ }^{11}$ Namun, apabila penggantian itu didasari oleh motif yang tidak benar seperti yang terjadi dalam

9 William L. Holladay, A Concise Hebrew and Aramaic Lexicon of the Old Testament (Grand Rapids, Ml: Eerdmans, 1988) 118.

10 David Daube, "Absalom and The Ideal King", dalam Vetus Testamentum 48/3 (Juli 1998) 317, berpendapat bahwa usaha Absalom membunuh Amnon hanya akan terlaksana kalau Amnon merasa dirinya aman dan tidak dikejar-kejar sehingga dia tidak membutuhkan penjagaan khusus. Itulah sebabnya Absalom membiarkan 2 tahun berlalu tanpa ada kejadian apa-apa demi menghilangkan kecurigaan.

11 Alter, 271, membandingkan kisah ini dengan kisah pemerkosaan Dina oleh Sikhem yang juga menunjukkan ketidakhadiran Yakub, yang tidak bertindak apaapa, yang akhirnya membuat Simeon dan Lewi, anak-anak Yakub itu sendiri, yang bertindak melakukan balas dendam terhadap Sikhem. 
kasus Absalom, ${ }^{12}$ maka pasti akan terjadi kerusakan atau minimal ketidakstabilan relasi di antara mereka semua.

3. Melakukan evakuasi sementara untuk memberikan ketenangan emosional kepada Tamar. Terjemahan Indonesia, "Lalu Tamar tinggal di rumah Absalom, kakaknya itu, seorang diri" (ayat 20) bisa memberi kesan tindakan mengisolasi diri dan tidak mau bertemu dengan siapapun. Tapi berdasarkan terjemahan Ibraninya, "Dan Tamar tinggal dan mengungsi (to be desolate, ${ }^{13}$ to be remove from the contact with people $\left.{ }^{14}\right) \mathrm{di}$ rumah Absalom, kakaknya" tidak ditemukan kata "seorang diri" yang memberi kesan mengisolasi diri. Ini lebih tepat dipahami sebagai tindakan evakuasi atau pengungsian, bukan tindakan mengisolasi diri tanpa kehadiran seorangpun. Kalaupun ada usaha menghindari kontak dengan orang lain, itu pastilah tindakan awal dan sementara sifatnya, yang berguna untuk menjauhkan korban dari bahaya dan kerusakan yang lebih parah, seperti terlihat pada tindakan pengungsian pada umumnya, misal pengungsian karena bencana alam, dan sebagainya.

\section{ANALISA 2 SAMUEL 13:23-39}

Dalam bagian ini, pengarang (narator) memakai sudut pandang temporal untuk menciptakan "suspensi" atau kejutankejutan kepada pembacanya. ${ }^{15}$ Ini tampak dalam pendahuluan di ayat 23, "Sesudah lewat dua tahun, Absalom mengadakan

\footnotetext{
12 Lihat analisa Daube, 315, 317, yang mempertanyakan sikap diam Daud terhadap Amnon terkait kasus Tamar (dia memakai kata "absolute unmoved") dan mengkaitkan dengan fakta bahwa Amnon adalah anak pertama dan calon penggantinya (putra mahkota). Ini diperkuat tambahan teks LXX: " dia tidak mengguncang jiwa (maksudnya: mempertanyakan, menekan, atau bahkan memberikan hukuman tertentu terhadap) Amnon anaknya karena dia mencintainya sebab dia adalah anak pertamanya ". Ini semacam motif merelakan kebenaran tidak ditegakkan demi mengamankan suksesi. Di sisi lain, Absalom juga memiliki ambisi merebut status sebagai putra mahkota [tentang hal ini lihat komentar Roy Battenhouse, "The Tragedy of Absalom: A Literary Analysis" dalam Christianity and Literature, vol. 31 no. 3 (Spring 1982) 53].

13 Menurut The American Heritage Dictionary, $2^{\text {nd }}$ College Edition, s.v. kata "desolate" berarti "to rid or deprive of inhabitants" (menarik diri dari lingkungan).

14 Holladay, 376. Tetapi, penulis tidak mengikuti bentuk pasif dalam terjemahannya karena penulis lebih memilih untuk mempertahankan bentuk aktif, dan bukan pasif.

${ }^{15}$ Longman III, 148.
} 
pengguntingan bulu domba ...." Kalau menilik pernyataan di akhir ayat 22 yang memakai sudut pandang psikologis di mana narator mengetahui dan menyampaikan kepada pembaca (biasa disebut narator "yang maha tahu") ${ }^{16}$ tentang kebencian Absalom terhadap Amnon, seharusnya ayat 23 akan dimulai dengan kalimat semacam ini: "Sesudah lewat dua tahun, ada kesempatan bagi Absalom untuk membalaskan dendamnya kepada Amnon ...." Faktanya, teks dimulai dengan pernyataan umum tentang pengguntingan bulu domba yang merupakan sebuah peristiwa besar semacam perayaan dan pesta. ${ }^{17}$

Tentang dialog Absalom dan Daud, terlihat ada pengulangan tindakan dalam pola berurutan sebagai berikut:

a. Permohonan Absalom yang pertama: mengundang raja dan para pegawai (ay. 24)

b. Penolakan Daud yang pertama: jangan semua pergi (ay. 25a)

c. Desakan Absalom yang pertama (ay. 25b)

d. Penolakan kedua dan restu dari Daud (ay. 25c)

a'. Permohonan Absalom yang kedua: mengundang Amnon (ay. 26a)

b'. Penolakan Daud yang ketiga: untuk apa Amnon pergi? (ay. 26b)

c'. Desakan Absalom yang kedua (ay. 27a) d'. Izin dari raja (ay. 27b)

Berdasarkan struktur di atas, penulis melihat beberapa catatan penting terkait relasi Absalom dengan Daud, ayahnya:

1. Ada 2x permohonan Absalom yang ditolak 3x. Kembali ditemukan kesan kuat bahwa Daud tidak peka baik terhadap situasi yang terjadi maupun terhadap apa yang dipikirkan dan dirasakan Absalom. Permohonan Absalom yang pertama

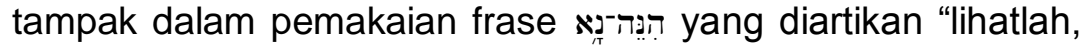
sekarang." Terkait apa yang dipikirkan Absalom, penulis melihat 2 kemungkinan berdasar pemakaian frase tersebut. Pertama, itu adalah ungkapan meminta perhatian yang urgen mengingat kurangnya perhatian Daud terhadap

\footnotetext{
${ }^{16} \mathrm{lbid}$

17 Lihat Alter, 271.
} 
Absalom (dan Tamar) dibandingkan terhadap Amnon. ${ }^{18}$ Kedua, itu adalah undangan basa basi Absalom karena sadar raja tidak terlalu peduli kepadanya, dengan harapan menyampaikan permohonan kedua yang menjadi tujuan utamanya. Logikanya menurut Alter, penolakan pertama yang memang sudah diantisipasi, akan memberikan urgensi lebih besar terhadap permohonan kedua. ${ }^{19}$ Dengan kata lain, Daud diperhadapkan pada perasaan serba salah apabila terus menerus menolak permohonan Absalom. Apapun kemungkinannya, Daud melewatkan kesempatan memperbaiki keadaan yang memburuk. Apabila dia menerima undangan Absalom dan pergi bersama para perwiranya, akankah terjadi pembunuhan terhadap Amnon? Ini dapat melunturkan perasaan pilih kasih atau diperlakukan berbeda di hati Absalom dan Tamar (bila merujuk pada kemungkinan pertama) atau mencegah secara alami tindakan Absalom yang anarkis dengan membunuh Amnon sekaligus tidak memberi ruang pada perasaan bersalah karena terus menolak permohonan Absalom (bila merujuk pada kemungkinan kedua).

2. Mengacu pada kemungkinan pertama di atas, penting untuk disadari bahwa orang yang merasa tidak diperhatikan akan meminta perhatian dengan cara yang kekanak-kanakan dan cenderung destruktif. Ini terjadi kemudian pada Absalom terkait dengan relasi dengan Yoab. Dalam rangka meminta perhatian Yoab, Absalom membakar ladang Yoab (14:28-32). Berdasarkan kemungkinan ini, tindakan anarkis Absalom dipahami sejajar dengan penolakan Daud atau lebih tepatnya, ketidakpekaan Daud terhadap sinyal minta perhatian dari Absalom. Ini semakin memicu dan memantapkan hasrat Absalom untuk membunuh Amnon, yang bukan hanya dipandang sebagai rival untuk posisi calon pengganti raja melainkan juga rival yang merebut kasih sayang Daud dari dirinya.

3. Mengacu pada kemungkinan kedua sesuai pendapat Alter di atas, maka kembali ditemukan pembalikan peran: seharusnya Daud yang lebih tahu dan lebih memahami Absalom; tetapi

\footnotetext{
${ }^{18}$ Perhatikan bahwa Amnon langsung dikunjungi saat dia berpura-pura sakit (ay. 6) sedangkan Tamar (dan Absalom) tidak dikunjungi dan diperhatikan.

${ }^{19}$ Alter, 272.
} 
faktanya, Absalomlah yang lebih memahami tabiat ayahnya! Ini sungguh ironis, khususnya karena pemahaman Absalom terhadap ayahnya justru menjadi alat untuk menemukan celah dan melakukan tindakan yang menyakiti hati ayahnya. Karena Absalom memahami tabiat ayahnya maka ia memakai taktik yang sama dengan taktik Amnon ${ }^{20}$ : sama seperti Amnon berhasil menipu Daud sehingga menyuruh Tamar menemui Amnon, demikian pula Absalom memakai taktik permohonan dan desakan hingga membuat Daud mengizinkan Amnon pergi ke tempat Absalom! Secara gramatika, ini dapat dilihat dari pemakaian artikel נָז pada ketiga permohonan tersebut (satu oleh Amnon dan dua oleh Absalom). Artinya, ada penyimpangan penggunaan permohonan yang bersifat segera namun dalam nuansa positif, menjadi alat untuk memuluskan rencana busuk mereka masing-masing.

4. Apapun kemungkinannya, teks menunjukkan adanya unsur prolepsis, yaitu semacam nubuatan atau pertanda (foreshadowing), untuk menjelaskan peristiwa yang akan terjadi atau tindakan yang akan dilakukan pada satu waktu tertentu. ${ }^{21}$ Pemakaian kata פָר Sebanyak 2x dan diterjemahkan "mendesak" dalam bahasa Indonesia digunakan pertama kali dalam Kej. 38:29 tentang kelahiran anak kembar Yehuda oleh Tamar (nama yang sama dengan adik Absalom! Incidental atau intentional?). Anak yang lebih kecil justru menerobos dan keluar terlebih dahulu sehingga diberi nama "Peres" yang berarti "menekan" atau "menerobos". Berdasarkan prinsip penyebutan pertama di mana sebuah kata memiliki arti yang tetap sama atau memiliki benih kebenaran yang akan dikembangkan dalam penyebutan berikutnya, ${ }^{22}$ dapat diyakini bahwa kata pada dasarnya berarti "(tindakan) menekan." Jadi, desakan Absalom terhadap Daud adalah semacam prolepsis yang sengaja dimasukkan oleh narator sebagai pertanda bahwa tindakan-tindakan

${ }^{20}$ Bandingkan juga dengan pendapat Alter, 272.

21 Tentang prolepsis, lihat David R. Bauer dan Robert A. Traina, Inductive Bible Study (Grand Rapids, MI: Baker, 2011) 146. Bauer dan Traina melihat prolepsis pada teks yang menginterupsi cerita, tetapi sesungguhnya prolepsis juga bisa terjadi pada pemakaian kata tertentu yang bermakna ganda seperti terlihat dalam analisa di atas.

${ }_{22}$ Lihat Kevin J. Conner dan Ken Malmin, Interpreting the Scriptures (Terj. Emma Maspaitella; Malang: Gandum Mas, 2004) 113. 
Absalom makin lama makin menjadi suatu tekanan bagi Daud, yang akhirnya (di pasal 15) membuatnya menyerah (sementara) dan memilih untuk keluar dari istana, dan bukannya melawan pemberontakan Absalom. Sama seperti desakan-desakan kecil yang tidak ditanggapi dan diantisipasi dengan tepat ${ }^{23}$ akan mengakibatkan tekanan-tekanan besar di masa mendatang yang memicu pengambilan keputusan secara tidak tepat, demikian juga "angin" masalah-masalah kecil di tengah keluarga Daud yang tidak tertangani dengan baik $^{24}$ akan menjadi bencana atau badai besar di kemudian hari.

Nuansa suspensi (ketegangan) dalam cerita ini terasa makin kental dengan penyajian karakter (characterization) 2 tokoh dengan karakter yang kompleks (round character). Yang pertama, tentang karakter Absalom. Dalam ayat 24-27, karakter Absalom lebih digambarkan dalam posisinya sebagai seorang anak yang merengek-rengek (meminta dan memohon sampai dikabulkan) kepada ayahnya. Tetapi segera setelah dikabulkan, gambaran karakternya berubah $180^{\circ}$. Ayat 28 menunjukkan bahwa Absalom dengan tegas memerintahkan anak buahnya untuk bertindak dengan berani dan gagah perkasa dan membunuh Amnon tanpa takut. Perubahan karakter ini jelas terlihat dengan pemakaian

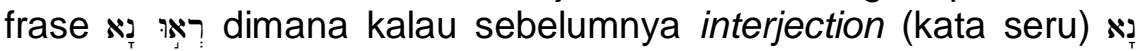
menunjukkan permohonan semacam "I beg you" (saya memohon padamu), dalam bagian ini berarti "emphatic do" (penekanan untuk melakukan sesuatu) sehingga menjadi semacam perintah ${ }^{25}$ dan dapat diterjemahkan "Do see?" (Lihatlah dengan sungguhsungguh!). Karakter Absalom kembali berubah dan tidak menunjukkan sikap berani dan gagah seperti yang diperintahkannya kepada anak buahnya. Setelah anak-anak raja berhasil melarikan diri dan pasti akan melaporkan peristiwa itu kepada Daud, dia justru melarikan diri. Yang kedua terkait karakter

${ }^{23}$ Kembali narator memakai teknik penghilangan (omissions) terkait pertanyaan Daud, " Untuk apa atau mengapa dia (Amnon) pergi denganmu?" yang tidak ada jawabannya dan " dikalahkan " oleh desakan Absalom.

24 Terjemahan Indonesia, "diizinkannyalah Amnon...." (ay. 27) kurang jelas.

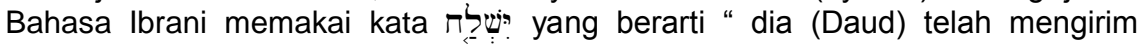
Amnon...." Ini menunjukkan bahwa Daud telah mengambil keputusan, tetapi sayangnya keputusan yang diambil kurang atau tidak bijaksana.

${ }_{25}$ Lihat penjelasan P. Jouon dan T. Muraoka, A Grammar of Biblical Hebrew (Roma, Italia: GBP, 2006), 322. 
Yonadab. Setelah sebelumnya Yonadab digambarkan sebagai tokoh yang cerdik tapi licik (pasal 13), dalam bagian ini Yonadab justru menjadi informan utama yang memberikan informasi valid atas apa yang terjadi pada anak-anak Daud: bahwa hanya Amnon, dan bukan semua anak Daud, mati dibunuh oleh Absalom (ay. 32). Menurut Hill, sejak semula Yonadab berkonspirasi dengan Absalom untuk menyingkirkan Amnon sebagai Putera Mahkota (dan "The Next King") dengan mengorbankan Tamar. ${ }^{26}$ Penulis tidak setuju terhadap wacana mengorbankan Tamar oleh Absalom, mengingat perhatian besar yang dilakukan Absalom paska peristiwa pemerkosaan oleh Amnon. Menurut hemat penulis, cukup dipahami ada gerakan-gerakan sporadis antara berbagai pihak, minimal di pihak Absalom dan di pihak Yonadab, yang ingin menggoyang posisi Amnon sebagai Putera Mahkota. Tentang Yonadab, ini dibuktikan oleh pengetahuannya bahwa bukan semua anak raja, melainkan hanya Amnon yang terbunuh, sebelum anak-anak raja itu datang dan memberitahukan apa yang telah terjadi. ${ }^{27}$ Artinya dia memiliki informasi dari orang penting yang hadir pada acara pengguntingan bulu domba tersebut dan memiliki kepentingan tertentu yang tidak disebutkan dalam teks. Karena tidak ada tanda sedikitpun tentang relasi Yonadab dengan Absalom, teori konspirasi Absalom dan Yonadab penulis anggap terlalu spekulatif. Cukup untuk dipahami bahwa Yonadab, yang dianggap sebagai orang yang berhikmat (mungkin cerdik tetapi licik), memahami situasi yang berkembang, dan khususnya bahasa tubuh Absalom yang menyimpan dendam terhadap Amnon. Fakta ini justru kembali menegaskan kekurangan Daud yang tidak memahami apa yang sesungguhnya dirancang oleh Absalom, anaknya. Ini terbukti melalui analisa karakter Daud dalam teks yang cenderung digambarkan sebagai karakter datar (flat character) karena sejak semula tidak dapat mencium gelagat buruk Absalom. Daud terlihat hanya mengikuti arus: setelah sempat sedikit mempertanyakan alasan mengundang Amnon, Daud hanya menuruti saja; saat mendengar rumor semua anak raja meninggal, Daud kembali langsung percaya tanpa mengecek kebenarannya; setelah anak-anak raja kembali dan menangis karena tragedi Amnon, Daud kembali mengikuti dan menangis dengan suara keras.

${ }^{26}$ Andrew E. Hill, "A Jonadab Connection in the Absalom Conspiracy?" dalam JETS 30/4 (December 1987), 389.

${ }^{27}$ Sama dengan pendapat Hill, 390. 
Penulis menyimpulkan bahwa sisi melankolis Daud sangat mendominasi teks ini, bahkan sampai pasal berikutnya: mengoyakkan pakaian dan berbaring di lantai (ay. 31); menaruh pikiran dalam hatinya (ay. 33; ungkapan yang mirip dengan nasihat Absalom kepada Tamar di ay. 20); menangis dengan amat keras (ay. 36); berduka cita berhari-hari lamanya (ay. 37); tidak lagi marah (ay. 39; harus dipahami dalam konteks "kemarahan dalam hati " karena tidak ditemukan langkah-langkah strategis seperti usaha menangkap Absalom, dan sebagainya); kesedihan hatinya ... telah surut (ay. 39); dan puncaknya di 14:1, "hati raja merindukan Absalom...." Sisi melankolis yang terungkap di pasal ini menunjukkan sisi melankolis yang melemahkan kepemimpinan Daud, yang membuatnya tidak berdaya. Ini tampak dalam komentar dan perintah Absalom yang terkesan dipakai narator untuk membandingkan dengan sisi melankolis yang melemahkan Daud tersebut. Komentar Absalom kepada anak buahnya supaya jangan takut atau jangan ragu-ragu bertindak terhadap Amnon dapat dipahami sebagai keteguhan hati untuk melakukan sesuatu (meskipun dalam konteks negatif) yang dapat dibandingkan dengan ketidakhadiran keteguhan hati Daud dalam menghadapi belitan masalah di antara anak-anaknya. Demikian pula dengan pemakaian kata kerja צָז sebanyak 2x dalam bentuk Piel perfek menunjukkan kemantapan hati Absalom (meskipun sekali lagi dalam konteks negative) untuk memberikan perintah yang kuat, yang akan dilaksanakan oleh anak buahnya. Sekali lagi ini dibandingkan dengan ketiadaan perintah dari Daud dalam mengatasi masalah. Perbandingan seperti itu kembali akan ditemukan dalam pasal-pasal berikutnya, khususnya antara sisi melankolis yang melemahkan kepemimpinan Daud (pasal 14) yang dibandingkan dengan sisi melankolis yang justru menguatkan kepemimpinan Daud di tengah krisis (pasal 15 dan selanjutnya).

\section{ANALISA 2 SAMUEL 14}

Pasal 14 melanjutkan penggambaran sosok Daud dengan sisi melankolis yang melemahkan diri dan kepemimpinannya. Pasal ini dimulai dengan pengamatan Yoab bahwa "hati raja merindukan Absalom" yang secara literal diterjemahkan "hati raja ada pada Absalom". Secara alami, frase ini menandakan bahwa pikiran raja sepenuhnya tertuju pada Absalom sehingga tidak ada ruang untuk memikirkan yang lain. Namun menurut Camp, entah 
persoalan harga diri ataukah status hukum (mengingat Absalom adalah pembunuh Amnon, anak Daud) yang menghalangi Daud untuk menemui atau memanggil pulang Absalom. ${ }^{28}$ Artinya, secara konsisten Daud "terkunci" dalam posisi dilematis atau serba salah $^{29}$ terkait rangkaian masalah seputar relasi dengan anakanaknya sehingga membuatnya tidak dapat mengambil tindakan atau keputusan yang tepat. Dan dia membutuhkan peran seorang Yoab untuk dapat menolongnya keluar dari posisi dilematis tersebut. Tetapi ironisnya, bahkan setelah Absalom kembali dengan bantuan Yoab, Daud justru tetap memperlakukan Absalom seperti orang yang diasingkan! Berdasarkan perkataan-perkataan hikmat perempuan dari Tekoa yang dipengaruhi secara kuat oleh Yoab, ada beberapa rangkaian tindakan bijaksana yang seharusnya dilakukan Daud, tetapi ternyata tidak dilakukannya.

1. Menjadi penengah di tengah konflik yang terjadi. Dalam perumpamaannya, perempuan dari Tekoa menyebutkan bahwa "tidak ada yang memisahkan" (ay. 6). Kata "memisahkan" memakai kata dasar נָָָָ yang berarti "melepaskan, membebaskan". Jadi, yang diharapkan adalah memisahkan untuk melepaskan atau membebaskan mereka dari konflik yang terjadi. Tetapi karena tidak ada yang memisahkan, maka terjadilah konflik berkepanjangan yang membelenggu mereka, khususnya dendam berkepanjangan di hati Absalom. ${ }^{30}$

${ }^{28}$ Claudia V. Camp, "The Wise Women of 2 Samuel: A Role Model for Women in Early Israel? dalam CBQ 43/1 (January 1981), 14. Penulis memahami frase "...prevents David from acting at once..." sebagai "...menghalangi Daud bertindak sekaligus..." yaitu "merindukan/memikirkan dan mendatangi atau memanggil pulang."

${ }_{29}$ Dalam ulasannya (book review) terhadap buku Larry L. Lyke (King David with the Wise Woman of Tekoa), Bernard S. Jackson memaparkan posisi Daud yang dilematis, apakah dia harus membunuh Absalom (melalui perintah kepada anak buahnya), memanggil Absalom pulang ke Yerusalem, ataukah membiarkannya tetap berada di pengungsian [lihat analisanya dalam JSOT 79 (June 1998) 123].

30 Halpern, 42-43, menggambarkan Absalom sebagai "viper" (ular berbisa). Artinya, seperti ular yang mengendap-endap menunggu waktu yang baik untuk melaksanakan dendamnya kepada Amnon. Halpern menghitung bahwa Absalom rela menanti selama 11 tahun hingga akhirnya melaksanakan misi lamanya untuk membunuh Amnon. 
2. Mencegah agar konflik tidak makin meluas. ${ }^{31}$ Meskipun tidak diceritakan secara rinci tentang reaksi para istri dan anak-anak Daud beserta keluarga mereka masing-masing, ada kemungkinan konflik yang tidak diselesaikan akibat pembunuhan Amnon oleh Absalom minimal memicu gonjangganjing $^{32}$ di antara keluarga besar Daud. Tidak ada ketegasan di pihak Daud seperti pemanggilan, penangkapan, atau pengarahan pasti memicu setiap pihak berpikir untuk melakukan apa yang benar menurut pendapat mereka masingmasing. Dalam konteks situasi seperti inilah mengapa akhirnya Yoab (di pasal 18) tanpa ragu membunuh Absalom, yang jelas merupakan ketidak-taatan terhadap perintah Daud, yang dianggap terlanjur tidak tegas dalam menangani kasus Absalom.

3. Menyelesaikan masalah dengan bijak. Kata-kata perempuan Tekoa, "Oleh karena tuanku mengucapkan perkataan ini (yaitu jaminan raja bahwa tidak ada pembunuhan terhadap si pembunuh, ay.11b), maka tuanku sendirilah yang bersalah dengan tidak mengizinkan pulang orang yang telah dibuangnya (lihat ay. 13) harus dipahami sebagai tindakan "menggantung masalah". Di satu sisi, tidak ada tindakan jelas dan tegas terhadap kejahatan yang dilakukan; di sisi lain, hukuman dengan waktu tak terhingga telah dijatuhkan secara tidak langsung, yaitu pembiaran terhadap Absalom yang tetap ada di pembuangan. Rupanya tindakan pembiaran inilah yang menjadi senjata Daud karena bahkan setelah Absalom dipanggil pulang, Absalom tidak diperkenankan bertemu raja sampai 2 tahun lamanya (ay. 24, 28). Jadi, terlihat ada urutan penanganan masalah yang salah. Seharusnya, Daud memanggil pulang Absalom, dan bertemu dengannya untuk

31 Ini tampak dalam kata-kata perempuan Tekoa di ay. 11, yang menurut John Joseph Owen, Analytical Key to the Old Testament, vol. 2: Judges - Chronicles (Grand Rapids, Ml: Baker, 1992), 335, diterjemahkan: 'Biarlah raja meminta pertolongan pada Tuhan, Allahmu, dari makin banyaknya penuntut tebusan darah (yang) membunuh dan janganlah anakku dimusnahkan." Jadi diharapkan ada keputusan strategis dan kepastian hukum demi mencegah ketidakpuasan/ dendam yang makin meluas sehingga saling merugikan dan saling menyakiti.

${ }^{32}$ Karena bersifat perumpamaan yang cenderung hiperbolik, kata-kata " seluruh kaum keluarga bangkit melawan ..." (ay. 7) tidak harus dimengerti harafiah tentang adanya unjuk rasa keluarga terhadap Absalom. Jadi minimal terjadi gonjang-ganjing dan pemikiran di antara anggota keluarga raja tentang apa yang harus dilakukan sebagai respons terhadap kasus Absalom. 
membicarakan masalahnya, lalu memberikan disiplin atau hukuman tertentu dalam jangka waktu tertentu, serta akhirnya memberikan pemulihan, seperti yang ditegaskan dalam katakata perempuan Tekoa: "...tetapi Dia (Tuhan) merancang supaya seorang yang terbuang jangan tinggal terbuang dari pada-Nya" (ay. 14). Penulis menyetujui penerjemahan Kronholm, “... (tetapi Dia) memikirkan rencana untuk tidak membuang orang yang telah terusir daripada-Nya" dengan pemahaman bahwa tindakan membuang berasal dari subyek yang sama, yaitu Tuhan dan orang Israel (dalam hal ini Daud) secara bergantian. ${ }^{33}$ Artinya, sama seperti Tuhan yang mungkin saja "mengusir" (dalam konteks: menghukum) seseorang tetapi tetap tidak akan membuang (yaitu: memberi kesempatan untuk bertobat) demikian pula halnya dengan manusia: Daud sebagai raja memiliki hak untuk menghukum Absalom karena kesalahannya, tetapi bukan dengan motivasi menghancurkan hidupnya melainkan dengan harapan agar Absalom berubah dan bertobat.

4. Menyampaikan kata-kata yang menenangkan hati. Harapan perempuan dari Tekoa ini secara literal berbunyi demikian: "...biarlah perkataan tuanku raja akan menjadi tempat peristirahatan...." Kata "peristirahatan" juga dipakai dalam Yes. 28:12-16 terkait anjuran Tuhan yang ditolak para pemimpin Yerusalem yaitu agar mereka masuk ke tempat perhentian agar disegarkan dari kelelahan mereka dan tempat

33 T. Kronholm, "נָדָח," dalam Theological Dictionary of the Old Testament, vol. IX (eds. G. Johannes Botterweck, Helmer Ringgren, dan Heinz-Josef Fabry; Grand Rapids, MI: Eerdmans, 1998), 237. Meskipun demikian penulis lebih menyetujui pendapat Martin G. Klingbeil, "דרחה," dalam New International Dictionary of Old Testament Theology and Exegesis, vol. 1 (eds. Willem A. VanGemeren; Grand Rapids, MI: Zondervan, 1997), 933 yang didukung Holladay, 69, yang

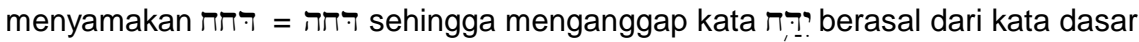

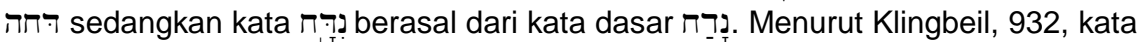
dasar דָד berarti " be pushed down, be thrust down, be cast out " (terdorong hingga jatuh atau terlempar keluar) sehingga menurut Holladay, 69, mengandung konotasi " be dispossessed " (tercabut hak kepemilikannya), sedangkan kata dasar נָרבָ menurut Owen, 336, berarti " be banished " (terusir). Kesimpulannya, tidak ada intensitas atau peningkatan hukuman: dari terusir kemudian tercabut hak kepemilikannya (atau sungguh-sungguh terlempar atau terbuang sama sekali). Seharusnya tetap ada kesempatan bagi mereka yang terusir (atau: melarikan diri) untuk dapat pulang kembali setelah bertobat tanpa kehilangan hak kepemilikannya seperti contoh perumpamaan anak yang hilang (Lukas 15:11-32). 34 Brown, Driver, dan Briggs, 630. 
perhentian itu adalah Sion, lambang kehadiran Allah di Israel. Sedangkan Mazmur 23:2 menjanjikan ketenangan (quietness) terhadap tiap pribadi yang mau dibimbing Allah. Terkait peran Daud sebagai pemimpin, adalah penting baginya untuk datang ke tempat perhentian di hadapan Tuhan agar mendapatkan ketenangan, dalam arti mendengar dan akhirnya memahami apa yang benar dan yang jahat ${ }^{35}$ dan mengalami penyertaan Tuhan $^{36}$ sehingga dapat bertindak secara tepat. Terhadap Absalom, seharusnya Daud berupaya menenangkan hati Absalom yang mengembara. Tindakan menenangkan hati bukan hanya diartikan menolong yang ketakutan, cemas, kuatir agar menjadi tenang, tetapi terutama membimbingnya untuk menemukan dan hidup dalam kebenaran (yang ditandai dengan kemampuan membedakan apa yang baik dan apa yang jahat). Absalom terlihat ketakutan seperti terlihat dalam usaha melarikan diri setelah membunuh Amnon (13:37) dan pasrah kalau Daud memberikan hukuman mati kepadanya $(14: 32)$ tetapi semuanya justru berbalik menjadi sikap perlawanan terhadap Daud karena tidak adanya kemampuan untuk membedakan apa yang benar dan apa yang jahat di pihak Absalom dan tidak adanya usaha pendekatan untuk menenangkan hati dan menyampaikan kebenaran di pihak Daud.

5. Memberikan teladan hidup. Segera setelah dialog dengan perempuan Tekoa, narator menyebutkan keputusan Daud yang meminta Absalom pulang tetapi tidak mau bertemu dengannya (ay. 24) yang segera disusul dengan deskripsi kegagahan Absalom (ay. 25). Terkait kegagahan Absalom, perlu diperhatikan komentar Macwilliam tentang kecantikan laki-laki yang biasa dihubungkan dengan kekuasaan sementara Macwilliam lebih menghubungkan dengan "nasib" yang harus dibayar Absalom karena dosa Daud. ${ }^{37}$ Penulis tidak setuju dengan pendapat ini karena terkesan mengandaikan apa yang dialami Absalom sepenuhnya

\footnotetext{
35 Secara literal, " membeda-bedakan apa yang baik dan jahat " (ay. 17) diterjemahkan " dapat mendengar yang baik dan yang jahat ".

${ }^{36}$ Secara literal, " dan TUHAN Allahmu menjadi bersama-sama dengan tuanku raja" penulis pahami sebagai pembuktian kehadiran Allah dalam hidupnya, bukan tindakannya yang menentukan Tuhan hadir atau tidak.

37 Stuart Macwilliam, "Ideologies of Male Beauty and the Hebrew Bible ", in Biblical Interpretation 17 (2009) 265, 282, 285.
} 
kesalahan Daud. Penulis lebih melihat ini sebagai kegagalan Daud mengajarkan dan "mentransfer" imannya kepada anakanaknya, termasuk Absalom. Ini khususnya tampak dalam komentar tentang kegagahan rambut Absalom yang fenomenal yang mengawali ketenarannya sebagai putera raja tetapi juga diakhiri dengan kematian Absalom yang berawal dari tersangkutnya rambut Absalom yang panjang pada sebuah pohon. Jadi narator memakai gaya bahasa alusio untuk membandingkan rambut panjang Absalom yang dipotong dengan domba yang dipotong bulunya untuk menegaskan bahwa fokus Absalom pada sisi lahiriah justru membawanya ke dalam kehancuran. Tetapi di sisi lain, tidak ditemukan catatan tentang nasihat Daud kepada Absalom agar tidak bersandar pada kekuatan lahiriah, padahal konsep itulah yang membuat Daud menjadi raja mengingat Tuhan menolak semua anak Isai lainnya, yang secara lahiriah terlihat lebih kuat daripada Daud! $!^{38}$ Penolakan Daud untuk bertemu Absalom (ay. 24) dilihat narator memicu konsep pementingan diri pada penampilan dan kekuatan lahiriah (ay. 25) ${ }^{39}$ yang sejajar dengan penerimaan normatif dan bukan penerimaan karena relasi paternal (yaitu kerinduan ayah yang ingin bertemu anaknya, lihat ay. 33) yang dilihat narator langsung memicu usaha pemberontakan di hati Absalom (15:1ff). ${ }^{40}$

\footnotetext{
${ }^{38}$ Lihat pendapat Fokkelman yang dikutip tetapi ditolak oleh Macwilliam, 282, yang mungkin didasari anggapan bahwa kegagalan Absalom sepenuhnya adalah kesalahan Absalom. Dalam pengertian yang paling esensi, justru penulis setuju bahwa setiap orang harus bertanggung jawab terhadap kesalahannya sendiri dan bukan menyalahkan lingkungan atau orang sekitarnya. Tetapi di sisi lain, kelemahan Daud juga turut memberikan sumbangsih bagi kegagalan Absalom.

39 Konsep pementingan diri ini mengkristal pada pembuatan monumen peringatan diri oleh Absalom (lihat 18:18). Tentang hal ini, Absalom beralasan bahwa ini perlu dilakukan mengingat dia tidak memiliki anak laki-laki. Padahal, menurut 14:27, dia memiliki 3 anak laki-laki. Tentang hal ini penulis lebih setuju dengan pendapat Alter, 307, yang hanya menyebutkan bahwa kemungkinan 3 anak laki-laki Absalom mati muda sehingga namanya dibiarkan tidak dicatat, dan menolak spekulasi Halpern, 387, bahwa Daud membunuh ketiga anak Absalom pada waktu Absalom melarikan diri ke Gesur untuk mengatasi pemberontakan. Pendapat Halpern kurang dapat diterima mengingat pada masa Absalom melarikan diri, belum ada usaha pemberontakan dari Absalom dan raja sangat merindukan Absalom meskipun juga marah (tanpa tahu apa yang harus dilakukan) terhadap apa yang dilakukan Absalom.

40 Alter, 282, menyebut pemakaian kata benda "raja" dan bukan nama Daud sendiri menunjukkan bahwa penerimaan Daud lebih bersifat formal atau tata cara kerajaan dan bukan penerimaan didasarkan relasi ayah dan anak, sehingga
} 


\section{ANALISA 2 SAMUEL 15-17}

Berbeda dengan pasal 13 yang memakai sudut pandang temporal dengan segala unsur suspensinya, pasal 15 memakai sudut pandang spatial dengan narator ada di mana-mana (omnipresent) untuk melaporkan pikiran dan tindakan tokoh-tokoh penting di dalam cerita ini. ${ }^{41}$ Dan berbeda dengan pasal 14 , pasal 15 menampilkan sisi melankolis Daud yang justru memperkuat diri dan kepemimpinannya di saat krisis. Ada beberapa gaya bahasa yang dipakai narator. Pertama, gaya bahasa penghilangan (omissions): ...demikianlah Absalom mencuri hati orang-orang Israel." Pertanyaannya, mencuri dari siapa? Ini sengaja dihilangkan justru untuk menimbulkan pertanyaan di hati pembaca. Minimal ada 2 kemungkinan. Kemungkinan pertama, Absalom mencuri hati orang-orang Israel dari Daud, raja mereka yang sah. Menurut Holladay, itu terkait dengan berpindahnya kesetiaan (loyalty) orang Israel dari Daud kepada Absalom. ${ }^{42}$ Kemungkinan kedua, Absalom telah mencuri hati orang-orang Israel dari kebenaran. Mereka telah dibutakan sehingga melihat secara sekilas dan hanya berdasarkan anggapan dangkal bahwa perkara mereka tidak dipedulikan oleh pihak kerajaan. Ini lebih mengarah pada kondisi "termakan hasutan Absalom". ${ }^{43}$ Padahal jelas dalam banyak kasus, raja Daud mendengarkan keluhan dan masalah masyarakat, termasuk dalam kisah perempuan Tekoa yang semula dianggap Daud sebagai masalah keluarga perempuan tersebut. Kedua, gaya bahasa ironi: sementara relasi Absalom, anak Daud, sepenuhnya berseberangan dengan Daud di pasal ini melalui persepakatan gelap yang dilakukannya, relasi Daud

makin mengecewakan Absalom secara pribadi dan mendorong niatnya untuk melakukan pemberontakan.

${ }^{41}$ Longman III, 148.

42 Holladay, 63.

43 Kesimpulan penulis didasari analisa tindakan-tindakan Absalom yang sangat "intentional" atau sangat memiliki motif untuk menjauhkan rakyat dari Daud: "setiap pagi berdirilah Absalom..." (ay. 2); “...setiap orang yang memiliki perkara...dipanggil Absalom (ay. 2); "...dari pihak raja tidak ada seorangpun..." (ay. 3); "Sekiranya aku diangkat...setiap orang...boleh datang kepadaku..." (ay. 4); "Apabila seseorang datang mendekat...diulurkannyalah tangannya, dipegangnya orang itu dan diciumnya (ay. 5); “...diperbuat Absalom kepada semua orang Israel..." (ay. 6). Halpern, 363, menyimpulkan bahwa Absalom menjanjikan " everything to everyone". 
dengan Itai yang baru datang dan bergabung dengannya, ${ }^{44}$ juga relasi dengan teman-teman Daud lainnya, terlihat begitu solid. Mereka berani berkorban untuk mendukung Daud yang sedang mengalami masa sulit. Apakah Daud menjadi pola seorang pemimpin yang begitu dekat dengan para pendukung dan anak buahnya sementara relasinya dengan anggota keluarganya sendiri terlihat berseberangan? Di sini terlihat kaitan erat antara sisi melankolis Daud berupa perhatian kepada anak buahnya dengan sikap anak buahnya yang setia. Relasi erat keduanya justru memperkuat kepemimpinan Daud di masa sulit. Ketiga, gaya bahasa alusio: penyebutan " 600 orang " dan " sejak di Gat " (2 Sam. 15:18) menunjuk pada pengungsian terdahulu Daud ke negeri Filistin, tepatnya di kota Gat yang dipimpin oleh raja Akhis (lihat 1 Sam. 27:2ff). Kalau dirunut ke belakang, kemungkinan besar ini adalah orang-orang yang mendatangi Daud di gua Adulam dan yang diterima dengan baik oleh Daud tanpa mempedulikan latar belakang mereka (lihat 1 Sam. 22:1ff). Menarik untuk ditekankan bahwa kedatangan orang-orang tersebut di gua Adulam disebutkan dengan kedatangan dan partisipasi keluarga Daud. Jadi inilah yang hilang dalam hidup Daud. Jika dalam fase awal hidupnya, kolaborasi teman-teman dan keluarga mendapat perhatian dari dan memberikan dukungan kepada Daud, di masa selanjutnya justru hubungan keduanya jelas terpisah, khususnya terkait dengan Absalom: Daud hanya didukung oleh teman-temannya. Bahkan mulai pasal 15 dan seterusnya, keluarga Daud hanya disebut saja tanpa deskripsi dan koneksi lebih lanjut di antara mereka, misal memberi dukungan saat Daud susah, dan seterusnya (lihat 16:2; 19:5, 41). Dalam banyak teks, hanya disebutkan raja Daud tanpa rincian "beserta keluarganya" misal dalam 15:30 ketika "Daud mendaki bukit Zaitun sambil menangis...." Dalam ayat itu disebutkan seluruh rakyat ikut sedih bersama-sama Daud, tetapi tidak disebutkan secara langsung bahwa keluarganya juga turut sedih. Ini bukan berarti mereka tidak ada di sana atau tidak turut bersedih, tetapi ini menunjukkan peran mereka yang makin minimal di tengah krisis yang dialami Daud. Satu-satunya catatan tentang relasi Daud dengan gundik-gundiknya justru menyebutkan bahwa mereka terasing sampai hari mati mereka (20:3). Terakhir, catatan Daud

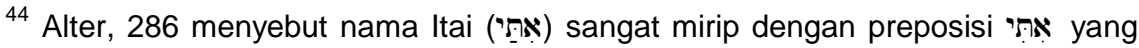
berarti " bersama dengan aku", yang menurut para ahli (Garsiel, Polzin, dan lainlain) berfungsi sebagai simbol kesetiaan (sikap loyal) Itai kepada raja. 
dalam relasi dengan keluarga hanya dicatat terkait pergantian kepemimpinan kepada Salomo (1 Raja-raja 1-2).

Berbeda dengan Daud, kesetiaan kepada Absalom terlihat instan dan tidak berakar kuat. Dalam tahap awal, mereka yang mendukung Absalom adalah para undangan yang pergi ke Hebron tanpa curiga dan tidak tahu apa-apa tentang rencana Absalom (ay.11). Meskipun langsung disebutkan bahwa makin banyak rakyat yang memihak Absalom (ay.12), tetapi menurut hemat penulis keberpihakan rakyat pada Absalom lebih didasari rasa takut daripada unsur loyal dan setia. Ini terbukti dengan tangisan rakyat sewaktu Daud dan rombongan mengungsi dan melarikan diri dari Absalom (ay.23). Itulah sebabnya mengapa rakyat setelah kematian Absalom langsung berpikir untuk mengembalikan jabatan raja kepada Daud, padahal sebelumnya rakyat telah mengurapi Absalom menjadi raja (19:10). Bahkan orang-orang terdekat Absalom seperti Ahitofel, ternyata taat demi menunaikan misi pribadinya sehingga segera setelah penolakan nasihatnya oleh Absalom, Ahitofel langsung bunuh diri (17:23). Sebagai tambahan, fakta tentang peran penting mata-mata Daud, Yonatan dan Ahimaas, yang berhasil lolos dan menyampaikan pesan penting kepada Daud serta menentukan arah strategi Daud menunjukkan soliditas kesetiaan orang-orang di sekitar Daud, baik yang dekat maupun yang jauh (ada di lokasi tempat Absalom berada). Sebaliknya, pengejaran Yonatan dan Ahimaas oleh orang-orang Absalom berhenti segera setelah mereka mengetahui bahwa Yonatan dan Ahimaas berhasil lolos, tanpa ada kelanjutan cerita, misalnya laporan kepada Absalom agar ada strategi alternatif terhadap kondisi terkini yang dihadapi. ${ }^{45}$

Menarik untuk diamati bahwa dalam situasi krisis yang sedang dihadapi, kepemimpinan Daud, yang sebelumnya terlihat sangat lemah terkait relasi dengan anak-anaknya, juga terlihat sangat kuat dan efektif. Terlihat bahwa ada relasi kuat antara sisi melankolis Daud yang begitu peduli terhadap anak buahnya dan sisi kolerik Daud yang begitu strategis dalam menentukan rencana

45 Lihat perbedaan kedua kelompok ini dalam 2 Sam. 17:20-21. Setelah mengetahui buronannya lolos, orang-orang Absalom "pulang ...ke Yerusalem." Tidak ada tindakan lainnya. Sementara setelah Yonatan dan Ahimaas lolos, nasihat mereka mengakibatkan Daud dan rombongan langsung bergerak menyeberangi Sungai Yordan. 
selanjutnya ${ }^{46}$ sehingga pembaca mendapat kesan bahwa strategi Daud ini sedemikian kuat dan efektif serta pasti akan memberikan hasil yang positif. Sebelumnya terkesan Daud gagal memimpin anak-anaknya dengan tegas karena terkesan terlalu sayang kepada anak-anaknya. Namun dalam bagian ini ditekankan bahwa kasih sayang dan perhatian yang benar, seperti yang ditunjukkan Daud kepada anak buahnya, justru memperkuat dan bukan memperlemah kepemimpinan Daud.

Selanjutnya dalam pasal 16-17, kembali narator menggunakan sudut pandang temporal untuk menambah efek suspensi di hati pembaca, ${ }^{47}$ khususnya terkait dengan ungkapanungkapan Daud yang pada saat itu belum mengetahui akhir petualangannya, apakah jabatan raja akan direbut oleh orang lain atau dikembalikan kepadanya. ${ }^{48}$ Menarik untuk dicatat bahwa di pasal 16, ada catatan tentang sisi religius Daud yang sempat hilang dan tidak dicatat sama sekali terkait dengan responss Daud menghadapi masalah yang menimpa anak-anaknya, khususnya seputar Amnon, Tamar, dan Absalom. Total terdapat 3 doa atau harapan Daud di hadapan Tuhan (2x dalam pasal 15 dan $1 \mathrm{x}$ di pasal 16). Yang pertama berupa doa penyerahan penuh, apakah Tuhan akan melakukan yang baik (yaitu: dikenan Tuhan) atau yang tidak di dalam hidupnya (15:25-26). Yang kedua berupa doa permohonan: "Gagalkanlah kiranya nasihat Ahitofel itu, ya TUHAN" (15:31). Dan yang terakhir berupa harapan Tuhan membalas apa yang buruk yang dilakukan Simei terhadapnya dengan apa yang baik, yang akan meredakan kesengsaraan yang sedang dialami (16:12). Kalau diperhatikan, terdapat nuansa menanjak di dalam ketiga doa yang disebutkan. Artinya, kesadaran dan keberanian untuk percaya penuh pada Tuhan, apakah Tuhan dapat melakukan apa yang baik atau mengijinkan yang tidak baik terjadi, menjadi momen pembangunan fondasi imannya sehingga dia dapat bangkit dari keterpurukan dan

46 Daud minimal begitu peduli pada Itai, Husai, serta kelompok Zadok dan Abyatar di 15:19-22, 24-29, 32-37.

47 Untuk studi lebih lanjut, lihat Jan Fokkelman, Di Balik Kisah-kisah Akitab (Jakarta: BPK, 2008), 183-89, khususnya tentang unsur ketegangan di seputar nasihat Ahitofel dan Husai.

48 Lihat analisa Halpern, 366, yang membuka kemungkinan bagi konspirasi antara Absalom dengan kaum Israel atau penduduk bagian Utara, seperti yang muncul dalam ungkapan Ziba terkait harapan Mefiboset (meskipun itu belum tentu benar dan mungkin sekali karangan Ziba sendiri): "Pada hari ini kaum Israel akan mengembalikan kepadaku kerajaan ayahku” (16:3). 
menggapai harapan baru di dalam Tuhan. Nuansa suspense menegaskan bahwa Daud tidak tahu akhir petualangannya, tetapi iman kepada Tuhan membawanya maju dan melangkah menuju masa depan dan harapan baru. Harapan baru itu minimal ditunjukkan melalui penanganan terhadap pemberontakan yang dilakukan oleh Seba tanpa menimbulkan gejolak baru di dalam pemerintahan Daud (lihat pasal 20).

\section{ANALISA 2 SAMUEL 18-19}

Pasal 18 dimulai dengan kesiapan hati Daud untuk memimpin pasukan menyerang kubu Absalom (ay. 1-2). Namun segera setelah dicegah oleh seorang tentara untuk tidak terjun langsung di medan pertempuran (ay. 3-4), Daud berpesan untuk memperlakukan Absalom dengan lunak (ay. 5). Menurut Alter, kata "dengan lunak" (gently) dipahami oleh para ahli bahasa memiliki akar kata yang sama dengan kata "menutupi atau melindungi" (to cover) seperti yang dipahami para prajurit Daud sebagai tindakan untuk mengamat-amati (to watch over) atau melindungi (to protect) Absalom (ay. 12). ${ }^{49}$ Tetapi instruksi ini ambigu sifatnya dan berpotensi membingungkan karena tidak jelas artinya, apakah membiarkan Absalom lepas atau menangkapnya hidup-hidup atau kemungkinan lainnya. Itulah sebabnya mengapa Yoab berpikir praktis ketika menemukan Absalom tidak berdaya dan memutuskan membunuhnya (ay. 14) karena menganggapnya sebagai lawan yang berbahaya. ${ }^{50}$ Demikian pula halnya dengan respons Yoab terhadap ratapan Daud setelah Absalom meninggal. Karena menganggapnya sebagai lawan yang berbahaya, ratapan Daud segera dipahami Yoab sebagai keberpihakan terhadap musuh, yang otomatis memposisikan Daud sebagai musuh rakyat Israel, seperti ungkapan Yoab: ... dengan mencintai orang-orang yang benci kepadamu, dan dengan membenci orang-orang yang cinta kepadamu..." (19:6). Sebenarnya, tindakan mencintai orangorang yang benci kepada Daud tidak selalu berarti membenci orang-orang yang selama ini cinta kepadanya atau berpihak

\footnotetext{
${ }^{49}$ Alter, 304.

50 Tentang kesimpulan sebagai lawan yang harus dihabisi, mungkin juga karena sikap Daud yang ambigu selama ini, yang puncaknya menyebut Abraham

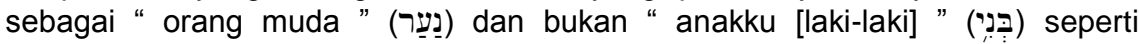
responsnya saat mendengar Absalom meninggal. Lagipula secara teks, kesiapan Daud memimpin pertempuran secara alami dianggap sebagai reaksi melawan musuh, yaitu Absalom.
} 
padanya. Itu dapat terjadi apabila Daud membedakan perlakuan atau tindakan hukum terhadap kesalahan Absalom yang jelas berusaha dan sudah merebut tahta Daud dengan perlakuan atau tindakan kasih kepada pribadi yang bersalah, yaitu Absalom dalam kapasitasnya sebagai anaknya. Tindakan pengampunan terhadap pribadi Absalom disertai pengarahan terhadap apa yang benar, yang seharusnya dilakukan Daud disediakan dalam dialog antara Ahimaas dan Yoab saat Ahimaas berinisiatif untuk menjadi pembawa berita kepada Daud. Dalam dialog tersebut, perkataanperkataan Yoab menjadi representasi motif yang salah dari Absalom atau Daud sementara sikap dan tindakan Ahimaas menjadi representasi apa yang baik, yang seharusnya dilakukan Daud. ${ }^{51}$ Minimal ditemukan 3 motif penting Ahimaas:

1. Bertindak bukan untuk memuaskan pribadi tertentu, tetapi untuk menyatakan kebenaran. Berdasarkan pemakaian kata

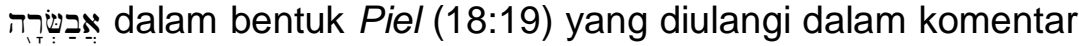
Yoab bahwa "...bukan engkau yang menjadi pembawa kabar, pada hari lain boleh engkau yang menyampaikan kabar..." (18:20) yang menegaskan bahwa memang Ahimaas dikenal sebagai pembawa berita. Tetapi terkait Absalom, Yoab melarang Ahimaas untuk menyampaikan berita dan meminta orang Etiopia sebagai antisipasi kemarahan Daud terhadap berita menyedihkan yang diterimanya. ${ }^{52}$ Jadi ada motif "meminjam tangan orang lain" agar tidak menerima resiko yang merugikan. Tetapi Ahimaas bersikeras karena dia tahu bahwa dia ingin mengabarkan kebenaran bahwa Tuhan telah memberi keadilan kepada Daud. Sepanjang sejarah dapat ditemukan orang-orang yang berani dan tetap menyampaikan kebenaran meskipun harus menerima resiko yang merugikan atau mengancam profesinya, keluarganya, atau bahkan nyawanya. Yang dilakukan Absalom sebaliknya. Dia memilih diam dan tidak mengambil resiko sampai kesempatan untuk membalas dendam terbuka lebar. Apabila sejak awal Absalom menemui Daud dan meminta kebenaran atas kasus Amnon dan Tamar, pasti akhir kisahnya berbeda. Demikian pula

51 Tentang representasi Ahimaas sebagai apa yang baik dapat ditemukan indikasinya dengan $2 x$ kali pengungkapan kata "baik" (18:27) baik terhadap pribadi Ahimaas maupun berita yang akan disampaikan.

52 Alter, 307, menyebut motif larangan Yoab adalah mengantisipasi eksekusi pembawa berita oleh Daud seperti dalam kasus berita kematian Saul oleh orang Amalek. 
halnya dengan Daud. Bila Daud tidak terbelenggu oleh relasi keluarga terhadap Amnon dan Absalom, pastilah dia dapat bertindak berdasarkan apa yang benar.

2. Bertindak bukan untuk mendapatkan keuntungan. Terhadap kemauan keras Ahimaas, Yoab mengungkapkan hal ini (18:22). Tetapi jawaban Ahimaas sederhana: "Apapun yang terjadi, aku mau berlari pergi" (18:23). Tidak ada motif keuntungan yang mendasari tindakannya untuk memberitakan kabar kematian Absalom. Ini berbeda dengan Absalom yang bertindak sebagai pembela orang Israel dengan cara mengambil keuntungan yaitu mendiskreditkan Daud (lihat pasal 15). Demikian juga halnya Daud yang tidak dapat bertindak tegas karena posisi Amnon sebagai Putera Mahkota. Berdasarkan karut marut keluarga Daud dapat disimpulkan bahwa ketika seseorang bertindak demi mencari keuntungan sesaat, maka kerugian yang berefek panjang justru akan dialami.

3. Bertindak bukan untuk mendapatkan posisi penting atau penghargaan orang lain. Gambaran pembawa berita yang berlari dominan dalam teks ini. Yang menarik, ada situasi pergantian berkali-kali siapa yang di depan dan siapa yang di belakang di antara Ahimaas dan orang Etiopia. Hingga akhirnya Ahimaas menjadi orang pertama yang menyampaikan berita kepada Daud. Tetapi karena informasi yang diterima tidak lengkap, dia diminta berdiri di samping (indikasi dikesampingkan?) dan digantikan oleh orang Etiopia dengan informasinya yang dijadikan pijakan bagi Daud. Tetapi yang menarik, tidak ditemukan ungkapan kekecewaan di hati Ahimaas. Kesan penulis setelah membaca berkali-kali teks ini adalah adanya "passion" (semangat dan kegairahan) yang kuatlah yang menjadi penggerak Ahimaas tetap mau memberitakan kabar kematian Absalom, yaitu keinginan yang kuat karena menganggap Tuhan telah menyatakan keadilanNya terhadap Daud, sehingga dia ingin menjadi orang pertama yang menyampaikan kabar itu kepada Daud. Berbeda dengan Ahimaas, Yoab berkali-kali melakukan tindakan-tindakan destruktif, termasuk yang terkini yaitu membunuh Amasa (lihat 20:10), karena Amasa telah diangkat Absalom dan tetap menjadi panglima menggantikan Yoab pada waktu posisi Daud kembali sebagai raja Israel (19:13). Absalom jelas melakukan 
hal yang sama. Dan akibatnya, dia meninggal dalam keadaan terhina. $^{53}$

4. Bertindak dengan bijaksana. Ini satu-satunya kekurangan Ahimaas. Dia hanya mengandalkan semangat, tetapi tanpa data dan informasi yang memadai sehingga dia tidak dapat menyebutkan apakah Absalom meninggal atau tidak. Padahal kalau dia tidak tergesa-gesa dan mengumpulkan info secara lebih teliti, akan terungkap bahwa Tuhan melalui kondisi alam, yaitu hutan Efraim, telah memperlakukan Absalom dengan "lembut" atau "lunak" seperti permintaan Daud. ${ }^{54}$ Menurut hemat penulis, bertindak dengan bijaksana tidak harus dipertentangkan dengan ketegasan untuk bertindak berdasarkan kebenaran dan bukan untuk mencari keuntungan pribadi atau bahkan mendapatkan posisi strategis. Sebaliknya, orang yang bijaksana tetap bisa bertindak tegas sesuai kebenaran tanpa terkesan melakukan sesuatu tanpa pertimbangan matang atau menjerumuskan diri sendiri ke dalam bahaya yang tidak perlu. Demikian juga orang yang bijaksana bisa saja tetap mendapatkan keuntungankeuntungan tertentu atau bahkan dipercaya untuk mendapatkan jabatan-jabatan strategis, tanpa perlu menggadaikan kebenaran yang diyakininya.

${ }^{53}$ Cara penguburan dengan cara melempar mayat ke dalam lobang yang besar menurut Alter, 306, adalah bentuk penguburan yang memalukan.

54 Lihat terjemahan Warren Baker, eds., The Complete Word Study Old Testament (Chattanooga, TN: AMG, 1994), 847, tentang permohonan Daud terkait Absalom: "Deal gently for my sake..." tetapi respons alam ada di ayat 8: "...dan hutan itu memakan lebih banyak orang di antara tentara daripada yang dimakan pedang pada hari itu." Perhatikan komentar di ayat 8 itu diletakkan langsung sebelum Absalom tersangkut kepalanya di pohon. 


\section{KESIMPULAN}

Setelah membaca teks seputar Daud dan Absalom, penulis diyakinkan bahwa masalah relasi yang tidak terjalin konstruktif di antara keduanya diakibatkan oleh hilangnya komunikasi langsung dua arah di antara keduanya. Hilangnya jenis komunikasi seperti itu coba dilengkapi oleh narator melalui berbagai cara. Pertama, menampilkan peran Absalom terhadap Tamar pasca pemerkosaan yang dilakukan Amnon, yang sebenarnya lebih tepat bila peran tersebut dilakukan oleh Daud sebagai ayah kandung Tamar. Kedua, menampilkan ketidakpekaan Daud terhadap permintaanpermintaan Absalom yang berujung pada pembunuhan terhadap Amnon. Penulis melihat jika Daud memenuhi permintaan untuk hadir dalam acara pengguntingan bulu domba, pertumpahan darah tidak akan terjadi. Ketiga, melalui nasihat tidak langsung dari perempuan Tekoa melalui rekayasa kasus yang sebenarnya mengandung tindakan-tindakan penting yang seharusnya dilakukan Daud untuk menyelesaikan masalah Absalom secara bijak. Penulis melihat semuanya ini adalah pemaparan tentang sisi melankolis Daud yang justru melemahkan kepemimpinan Daud, khususnya kepemimpinan dalam keluarga. Ironisnya, melalui pemaparan relasi dengan anak buah dan rekan-rekannya, Daud justru menampilkan sisi melankolis, yang bukan melemahkan, melainkan justru memperkuat sisi kolerik kepemimpinan Daud. Akhirnya, penulis melihat bahwa semua tragedi di tengah keluarga Daud seharusnya dapat diselesaikan dan tidak makin melebar apabila Daud meneladani prinsip-prinsip penting pelayanan yang dilakukan oleh Ahimaas. 